\title{
The effect of cycloheximide and growth regulators on the senescence of cut leaves in Hosta sp. and Zantedeschia aethiopica
}

\author{
Ewa Skutnik*, Julita Rabiza-Świder, Agata Jędrzejuk, Diana Musiat
}

Department of Ornamental Plants Faculty of Horticulture Biotechnology and Landscape Architecture Warsaw University of Life Sciences Nowoursynowska 166, 02-787 Warsaw, Poland

\begin{abstract}
The leaves of Zantedeschia and Hosta are used as florist greens in different floral arrangements. The most efficient postharvest treatment for cut foliage is the use of growth regulators, which prolong their vase life by delaying degradative changes occurring in leaves, especially proteolysis. Cycloheximide (CHI) is one of the protein synthesis inhibitors, blocking the enzymes responsible for decreasing membrane integrity, a phenomenon hastening senescence. The aim of this experiment was to evaluate the effects of CHI and benzyladenine (BA) or gibberellic acid $\left(\mathrm{GA}_{3}\right)$ on the longevity of cut foliage in hosta (Hosta sp.) cultivars and Ethiopian calla (Zantedeschia aethiopica) and to follow the changes in certain proteolytic processes occurring during senescence. Generally, $24 \mathrm{~h}$ conditioning with cycloheximide shortened the longevity of cut calla leaves while having no effect on hosta vase life. In ageing leaves of 'Minima Glauca' hosta and calla, the total proteolytic activity increased, including that of cysteine protease. Due to the application of BA or GA in hosta and calla, respectively, this activity was limited. On the contrary, the use of CHI either did not affect the activity of cysteine protease or increased it several-fold relative to the control, in hosta and calla, respectively. Leaves treated with growth regulators had many more soluble proteins and fewer free amino acids, including free proline, than leaves from other treatments. The highest free proline level was determined in calla leaves conditioned with $\mathrm{CHI}$, where it increased 18-fold relative to the initial level.
\end{abstract}

Key words: cut foliage, cysteine protease activity, free amino acids, free proline, proteolytic activity, vase life

\section{Abbreviations:}

BA - benzyladenine, CHI - cycloheximide, DTT - dithiothreitol (1,4-dithio-DL-threitol), d.w. - dry leaf weight, EDTA - ethylenediaminetetraacetic acid, GA - gibberellic acid, HEPES - (4-(2-hydroxyethyl)-1piperazineethanesulfonic acid), PGRs - plant growth regulators, TCA - trichloroacetic acid

\section{INTRODUCTION}

Today, green plant elements are indispensable in floral compositions. Most plants grown for florist greens come from the tropics (palms, ferns, vine leaves or leafy shoots of tropical shrubs) and are available on the market all year long. In the temperate zone, many plants can also be grown for this purpose, either under covers or in the open

\footnotetext{
*Corresponding author.

Tel.: +48 2259322 71; fax: +48 2259322 68;

e-mail: ewa_skutnik@sggw.pl (E. Skutnik).
} 
air. The latter include perennials, especially hostas (Hosta sp.), whose numerous cultivars provide leaves of different shapes, sizes and colours, available for harvest during nearly the entire vegetative period (between June and October). Another popular plant producing showy foliage is calla, both Ethiopian (Zantedeschia aethiopica (L.) Spreng.) and interspecific hybrids (Zantedeschia sp.). The former provides leaves during winter and early spring while the hybrids also in summer.

When used together with long lasting flowers, cut leaves of hosta and calla usually lose their decorative values first. This is due to their unbalanced water status after detachment from the mother plant resulting in the disruption of water uptake and the endogenous hormone supply from the plant roots. Their senescence can be delayed by synthetic hormones, cytokinins or gibberellins in hosta and calla leaves, respectively. In our earlier trials the $24 \mathrm{~h}$ conditioning of cut leaves of Hosta 'Undulata Erromena' with benzyladenine prolonged their longevity 6-fold relative to the control untreated leaves (Skutnik and RabizaŚwider 2005), while in calla a similar treatment with gibberellic acid prolonged foliage vase life 1.5-fold (Skutnik et al. 2001).

Senescence in leaves initiated by their detachment from the plant is associated with various biochemical and physiological changes. A drop in chlorophyll content is the first visual senescence symptom (Skutnik et al. 2004) and it is accompanied by protein degradation due to an increased activity of proteolytic enzymes (RabizaŚwider et al. 2003), resulting in the accumulation of free amino acids, including free proline and ammonium (Yang and Kao 2000, RabizaŚwider et al. 2004 a, b). Delaying proteolysis is fundamental for a delay of senescence. Hydrolysis of peptide bonds releasing amino acids is carried out by specific endo- and exoproteases. The final hydrolysis products (including ammonium) may be dangerous for cells so they are transformed into less toxic forms such as amides, which are also more easily transportable (Nooden and Guiament 1996). An application of protease inhibitors seems a logical solution when aiming to improve the longevity of cut foliage.

The aim of the experiment was to evaluate the effect of cycloheximide and growth regulators (BA and $\mathrm{GA}_{3}$ ) on longevity and processes occurring in senescing cut leaves of Hosta and Zantedeschia, including proteolytic activity and soluble protein content as well as the accumulation of free amino acids including free proline.

\section{MATERIAL AND METHODS}

The leaves of Zantedeschia aethiopica (L.) Spreng. and Hosta L. ('Golden Tiara', 'Minima Glauca' and 'Undulata Erromena') were harvested from the plant collections of the Department of Ornamental Plants of the Warsaw University of Life Sciences. Mature, undamaged leaves were cut in the morning and immediately transported to the laboratory, where they were graded for uniformity and conditioned. Hosta leaves were treated with BA $\left(0.1 \mathrm{mmol} \mathrm{dm}^{-3}\right)$ and Zantedeschia leaves with $\mathrm{GA}_{3}\left(0.25 \mathrm{mmol} \mathrm{dm}^{-3}\right)$ for 24 hours and placed in distilled water. Similarly, pulse conditioning ( 24 hours) with cycloheximide for hosta $\left(20,50,100,200,500 \mu \mathrm{mol} \mathrm{dm}{ }^{-3}\right)$ and for Ethiopan calla $(20,50,100,200,500,750,1000$ $\mu \mathrm{mol} \mathrm{dm} \mathrm{dm}^{-3}$ ) (Tab. 1) was also given for both genera under controlled conditions: temperature $20^{\circ} \mathrm{C}$, relative humidity $60 \%$, quantum irradiance of $35 \mu \mathrm{mol} \mathrm{m} \mathrm{m}^{-2} \mathrm{~s}^{-1}$, under the $12 \mathrm{~h}$ day and $12 \mathrm{~h}$ night regime. Unpulsed leaves held in water were treated as respective controls. There were 10 leaves in each treatment, individually tagged and treated as separate replications. Leaf vase life was considered as terminated when approx. $30 \%$ of blade surface was yellow or wilted. These symptoms were evaluated visually.

The subsequent experiments were carried out to follow and compare the biochemical changes in leaves and consisted of three treatments: water control, leaves treated with the CHI concentration that was the most effective for vase life (for Hosta 'Minima Glauca' $500 \mu \mathrm{mol} \mathrm{dm}{ }^{-3}$, for Z. aethiopica $1000 \mu \mathrm{mol} \mathrm{dm}-3$ ) and leaves conditioned $24 \mathrm{~h}$ with $0.1 \mathrm{mmol} \mathrm{dm}^{-3}$ benzyladenine or $0.25 \mathrm{mmol} \mathrm{dm}^{-3}$ gibberellic acid, in hosta and calla, respectively.

Samples for biochemical analyses were collected several times during the experiments, on days: 0 (immediately after cutting off), 13, 18 and 24 for Hosta 'Minima Glauca' and 0, 5, 11 and 15 for $Z$. aethiopica. The above dates were related to the senescence rate of the given taxon. The blades were finely chopped, mixed and $0.5 \mathrm{~g}$ samples were prepared. They were kept under $-80^{\circ} \mathrm{C}$ until analyses.

Total proteolysis and the activity of the cysteine protease were measured as described by Zagdańska and Wiśniewski (1996). Enzymes were extracted in HEPES with $1 \mathrm{mmol} \mathrm{dm}^{-3}$ DTT and $1 \mathrm{mmol} \mathrm{dm}^{-3}$ EDTA, pH 7.5. To determine total proteolysis, the extract was incubated $3 \mathrm{hrs}$ at $37^{\circ} \mathrm{C}$ with 
citric-phosphate buffer $\mathrm{pH} 5.0$ and azocasein. To determine the cysteine protease activity, $10 \mathrm{mmol}$ $\mathrm{dm}^{-3}$ iodoacetate was added to the extract-buffer mixture, with azocasein being included after one hour of incubation. The reaction was stopped by $24 \%$ TCA. Extinction was read against a blank at $340 \mathrm{~nm}$. The protease activity was calculated as a difference in readings with and without the iodoacetate. Results are given in arbitrary units which correspond to changes in absorbance of 0.01 during one hour, calculated on $\mathrm{mg}$ of protein in the sample as determined by the Bradford method (1976).

The soluble protein and free amino acid contents were determined according to Bradford (1976) and Rosen (1957), respectively, calculated from previously plotted standard curves, and expressed in $\mathrm{mg}$ of albumin bovine serum or $\mu \mathrm{mol}$ leucine, respectively, per gram of dry leaf weight (d.w.). Leaf tissue was dried at $105^{\circ} \mathrm{C}$ until a constant weight was achieved (Strzelecka et al. 1982). The free proline content was determined according to Bates et al. (1973) by measuring the quantity of the coloured reaction product of proline with ninhydric acid. The absorbance was read at 520 $\mathrm{nm}$. The amount of proline was calculated from the previously plotted standard curve and expressed in $\mu \mathrm{mol} \mathrm{g} \mathrm{g}^{-1}$ of d.w.

Results were statistically evaluated by ANOVA using the StatGraphics Plus program. Duncan's test at $p=0.05$ was applied to assess the significant differences between the means.

\section{RESULTS}

Generally, the treatments with CHI were ineffective and some even shortened foliage longevity. Only $\mathrm{CHI}$ in a concentration of $500 \mu \mathrm{mol} \mathrm{dm}{ }^{-3}$ prolonged the vase life of 'Minima Glauca' hosta, over $30 \%$ relative to the untreated control. Its lower concentration of $100 \mu \mathrm{mol} \mathrm{dm} \mathrm{dm}^{-3}$ increased leaf longevity by two days in hosta 'Undulata Erromena' (Tab. 1).

During the senescence of leaves in 'Minima Glauca' hosta, the proteolytic activity, including that of cysteine protease, increased (Tab. 2). The highest activities were found in the control leaves on the third sampling date ( 24 days after harvest); the total proteolytic activity and that of cysteine protease increased 5- and 10-fold, respectively, as compared to the initial measurement. On the $13^{\text {th }}$ day after harvest the proteolytic activity in leaves conditioned with $\mathrm{CHI}$ was approximately half of

Table 1. Effect of $24 \mathrm{~h}$ conditioning with cycloheximide on the postharvest longevity of cut leaves [days]

\begin{tabular}{|c|c|c|c|c|c|}
\hline \multirow{2}{*}{ Treatment } & \multicolumn{3}{|c|}{ Hosta } & \multicolumn{2}{|c|}{ Zantedeschia aethiopica } \\
\hline & Golden Tiara & Minima Glauca & Undulata Erromena & Experiment 1 & Experiment 2 \\
\hline $\mathrm{H}_{2} \mathrm{O}$ (control) & $16.5 \mathrm{a}^{*}$ & $17.4 \mathrm{~b}$ & $6.1 \mathrm{a}$ & $14.4 \mathrm{c}$ & $9.9 \mathrm{~b}$ \\
\hline $20 \mu \mathrm{mol} \mathrm{dm}{ }^{-3} \mathrm{CHI}$ & $13.0 \mathrm{a}$ & $11.4 \mathrm{a}$ & $7.8 \mathrm{ab}$ & $8.3 \mathrm{ab}$ & - \\
\hline $50 \mu \mathrm{mol} \mathrm{dm}{ }^{-3} \mathrm{CHI}$ & $12.4 \mathrm{a}$ & $17.8 \mathrm{~b}$ & $6.8 \mathrm{ab}$ & $7.9 \mathrm{a}$ & - \\
\hline $100 \mu \mathrm{mol} \mathrm{dm}{ }^{-3} \mathrm{CHI}$ & $13.1 \mathrm{a}$ & $21.1 \mathrm{~b}$ & $8.2 \mathrm{~b}$ & $9.2 \mathrm{ab}$ & - \\
\hline $200 \mu \mathrm{mol} \mathrm{dm}{ }^{-3} \mathrm{CHI}$ & $14.1 \mathrm{a}$ & $20.4 \mathrm{~b}$ & $7.3 \mathrm{ab}$ & $8.8 \mathrm{ab}$ & - \\
\hline $500 \mu \mathrm{mol} \mathrm{dm}{ }^{-3} \mathrm{CHI}$ & $13.8 \mathrm{a}$ & $22.9 \mathrm{c}$ & $7.2 \mathrm{ab}$ & $9.7 \mathrm{~b}$ & $8.0 \mathrm{a}$ \\
\hline $750 \mu \mathrm{mol} \mathrm{dm}{ }^{-3} \mathrm{CHI}$ & $-* *$ & - & - & - & $9.2 \mathrm{ab}$ \\
\hline $1000 \mu \mathrm{mol} \mathrm{dm}{ }^{-3} \mathrm{CHI}$ & - & - & - & - & $10.6 \mathrm{~b}$ \\
\hline
\end{tabular}

*Values in columns marked by the same letter do not differ significantly at $\mathrm{p}=0.05$ (Duncan's test)

**Not tested

Table 2. Effect of $24 \mathrm{~h}$ conditioning with cycloheximide or benzyladenine on the activity of proteolytic enzymes [unit $\mathrm{mg}$ (protein $)^{-1} \mathrm{~h}^{-1}$ in cut leaves of Hosta 'Minima Glauca'

\begin{tabular}{|c|c|c|c|c|c|c|c|c|c|c|}
\hline \multirow{2}{*}{ Treatment } & \multicolumn{4}{|c|}{ Total proteolytic activity on day } & \multirow{2}{*}{ Mean } & \multicolumn{4}{|c|}{ Cysteine protease activity on day } & \multirow{2}{*}{ Mean } \\
\hline & 0 & 13 & 18 & 24 & & 0 & 13 & 18 & 24 & \\
\hline $\mathrm{H}_{2} \mathrm{O}$ (control) & $0.8 \mathrm{a}^{*}$ & $6.9 \mathrm{bc}$ & $10.4 \mathrm{c}$ & $35.1 \mathrm{~d}$ & $13.3 \mathrm{~b}$ & $0.6 \mathrm{a}$ & $3.1 \mathrm{~b}$ & $10.2 \mathrm{c}$ & $32.0 \mathrm{~d}$ & $11.5 \mathrm{~b}$ \\
\hline $0.1 \mathrm{mmol} \mathrm{dm}{ }^{-3} \mathrm{BA}$ & $0.8 \mathrm{a}$ & $0.9 \mathrm{a}$ & $1.2 \mathrm{a}$ & $1.9 \mathrm{a}$ & $1.2 \mathrm{a}$ & $0.6 \mathrm{a}$ & $0.5 \mathrm{a}$ & $0.5 \mathrm{a}$ & $1.0 \mathrm{ab}$ & $0.7 \mathrm{a}$ \\
\hline $500 \mu \mathrm{mol} \mathrm{dm}{ }^{-3} \mathrm{CHI}$ & $0.8 \mathrm{a}$ & $3.8 \mathrm{ab}$ & $3.6 \mathrm{ab}$ & $38.0 \mathrm{~d}$ & $11.6 \mathrm{~b}$ & $0.6 \mathrm{a}$ & $2.2 \mathrm{ab}$ & $2.3 \mathrm{ab}$ & $31.3 \mathrm{~d}$ & $9.1 \mathrm{~b}$ \\
\hline Mean & $0.8 \mathrm{a}$ & $3.8 \mathrm{~b}$ & $5.1 \mathrm{~b}$ & $25.0 \mathrm{c}$ & & $0.6 \mathrm{a}$ & $1.9 \mathrm{ab}$ & $4.3 \mathrm{~b}$ & $21.4 \mathrm{c}$ & \\
\hline
\end{tabular}

*Values marked by the same letter do not differ significantly at $\mathrm{p}=0.05$ (Duncan's test) 
Table 3. Effect of $24 \mathrm{~h}$ conditioning with cycloheximide or benzyladenine on the soluble protein content [mg g $\mathrm{g}^{-1} \mathrm{~d}$.w.] in cut leaves of Hosta 'Minima Glauca'

\begin{tabular}{|c|c|c|c|c|c|}
\hline \multirow{2}{*}{ Treatment } & \multicolumn{4}{|c|}{ Soluble protein content on day } & \multirow{2}{*}{ Mean } \\
\hline & 0 & 13 & 18 & 24 & \\
\hline $\mathrm{H}_{2} \mathrm{O}$ (control) & $119.4 d^{*}$ & $109.9 \mathrm{~cd}$ & $85.2 \mathrm{ab}$ & $75.7 \mathrm{a}$ & $97.6 \mathrm{a}$ \\
\hline $0.1 \mathrm{mmol} \mathrm{dm}^{-3} \mathrm{BA}$ & $119.4 \mathrm{~d}$ & $146.4 \mathrm{e}$ & $114.0 \mathrm{~d}$ & $103.1 \mathrm{c}$ & $120.7 \mathrm{c}$ \\
\hline $500 \mu \mathrm{mol} \mathrm{dm}{ }^{-3} \mathrm{CHI}$ & $119.4 \mathrm{~d}$ & $113.7 \mathrm{~d}$ & $100.2 \mathrm{c}$ & $88.1 \mathrm{~b}$ & $105.4 \mathrm{~b}$ \\
\hline Mean & $119.4 \mathrm{c}$ & $123.3 \mathrm{c}$ & $99.8 \mathrm{~b}$ & $89.0 \mathrm{a}$ & \\
\hline
\end{tabular}

*Explanations: see Table 2

Table 4. Effect of $24 \mathrm{~h}$ conditioning with cycloheximide or benzyladenine on free amino acid content [ $\mu$ mol (leucine) $\mathrm{g}^{-1} \mathrm{~d}$.w.] and free proline content $\left[\mu \mathrm{mol} \mathrm{g}{ }^{-1} \mathrm{~d}\right.$.w.] in cut leaves of Hosta 'Minima Glauca'

\begin{tabular}{|c|c|c|c|c|c|c|c|c|}
\hline \multirow{2}{*}{ Treatment } & \multicolumn{3}{|c|}{ Free amino acids content on day } & \multirow{2}{*}{ Mean } & \multicolumn{3}{|c|}{ Free proline content on day } & \multirow{2}{*}{ Mean } \\
\hline & 0 & 13 & 18 & & 0 & 13 & 18 & \\
\hline $\mathrm{H}_{2} \mathrm{O}$ (control) & $367.5 \mathrm{a}^{*}$ & $673.2 \mathrm{~b}$ & $973.7 \mathrm{~d}$ & $671.5 \mathrm{~b}$ & $3.2 \mathrm{c}$ & $4.1 \mathrm{e}$ & $5.6 \mathrm{f}$ & $4.3 \mathrm{c}$ \\
\hline $0.1 \mathrm{mmol} \mathrm{dm}^{-3} \mathrm{BA}$ & $367.5 \mathrm{a}$ & $302.4 \mathrm{a}$ & $312.9 \mathrm{a}$ & $327.6 \mathrm{a}$ & $3.2 \mathrm{c}$ & $2.6 \mathrm{~b}$ & $2.1 \mathrm{a}$ & $2.6 \mathrm{a}$ \\
\hline $500 \mu \mathrm{mol} \mathrm{dm}{ }^{-3} \mathrm{CHI}$ & $367.5 \mathrm{a}$ & $693.8 \mathrm{~b}$ & $824.7 \mathrm{c}$ & $628.7 \mathrm{~b}$ & $3.2 \mathrm{c}$ & $3.7 \mathrm{~d}$ & $4.0 \mathrm{e}$ & $3.6 \mathrm{~b}$ \\
\hline Mean & $367.5 \mathrm{a}$ & $556.4 \mathrm{~b}$ & $703.8 \mathrm{c}$ & & $3.2 \mathrm{a}$ & $3.5 \mathrm{a}$ & $3.9 \mathrm{a}$ & \\
\hline
\end{tabular}

*Explanations: see Table 2

that in the untreated leaves but on the $24^{\text {th }}$ day it increased and attained the value determined in the control treatment. A similar tendency was observed in cysteine protease from the CHI-treated leaves. The lowest total proteolytic and cysteine protease activities were found in leaves conditioned with BA. On the $13^{\text {th }}$ day of vase life they did not differ from the initial values and increased only negligibly on the next dates (18 and 24 days after harvest).

Different results were obtained for calla (Tab. 5). Here the lowest proteolytic activity was found in the control untreated leaves, where it kept increasing during vase life, up to four times relative to the initial value on the $15^{\text {th }}$ day. In the $\mathrm{GA}_{3}$ conditioned leaves the activity increased 5-fold already on the first sampling date but remained stable till the end of the experiment. A significant increase in proteolytic activity occurred in calla leaves conditioned with $\mathrm{CHI}$ : almost 18 -fold as compared to the initial activity. Similar tendencies were observed for the activity of cysteine protease, which was the highest in the CHI-treated leaves, where it increased 12 times relative to the initial value and this increase occurred already on the $11^{\text {th }}$ day of vase life.

Both the treatment and the sampling date significantly affected the soluble protein contents in hosta leaves (Tab. 3). These contents decreased during leaf senescence in all of the treatments. Only in the BA-treated leaves on the $13^{\text {th }}$ day was the protein level higher than it was immediately after harvest, and it was also higher than in the control treatment and in the CHI-conditioned leaves. Similar results were obtained for calla (Tab. 6), where the $\mathrm{GA}_{3}$ conditioned leaves were also the richest in soluble proteins. On the last sampling date $\left(15^{\text {th }}\right.$ day), their content was only $6 \%$ lower than immediately after harvest while in the control leaves and those conditioned with $\mathrm{CHI}$ it fell by $50 \%$ and over 3 -fold, respectively.

Table 5. Effect of $24 \mathrm{~h}$ conditioning with cycloheximide or gibberellic acid on the activity of proteolytic enzymes [unit $\mathrm{mg}$ (protein $)^{-1} \mathrm{~h}^{-1}$ ] in cut leaves of Zantedeschia aethiopica

\begin{tabular}{|c|c|c|c|c|c|c|c|c|c|c|}
\hline \multirow{2}{*}{ Treatment } & \multicolumn{4}{|c|}{ Total proteolytic activity on day } & \multirow{2}{*}{ Mean } & \multicolumn{4}{|c|}{ Cysteine protease activity on day } & \multirow{2}{*}{ Mear } \\
\hline & 0 & 5 & 11 & 15 & & 0 & 5 & 11 & 15 & \\
\hline $\mathrm{H}_{2} \mathrm{O}$ (control) & $1.5 \mathrm{a}^{*}$ & $2.5 \mathrm{a}$ & $3.4 \mathrm{a}$ & $6.0 \mathrm{~b}$ & $3.4 \mathrm{a}$ & $1.3 \mathrm{a}$ & $1.7 \mathrm{a}$ & $2.7 \mathrm{~b}$ & $4.2 \mathrm{~d}$ & $2.5 \mathrm{a}$ \\
\hline $0.25 \mathrm{mmol} \mathrm{dm}^{-3} \mathrm{GA}_{3}$ & $1.5 \mathrm{a}$ & $7.2 \mathrm{bc}$ & $6.4 \mathrm{~b}$ & $6.9 \mathrm{bc}$ & $5.5 \mathrm{~b}$ & $1.3 \mathrm{a}$ & $1.7 \mathrm{a}$ & $2.6 \mathrm{~b}$ & $2.6 \mathrm{~b}$ & $2.1 \mathrm{a}$ \\
\hline $1000 \mu \mathrm{mol} \mathrm{dm}{ }^{-3} \mathrm{CHI}$ & $1.5 \mathrm{a}$ & $8.0 \mathrm{c}$ & $28.7 \mathrm{e}$ & $26.4 \mathrm{~d}$ & $16.2 \mathrm{c}$ & $1.3 \mathrm{a}$ & $3.7 \mathrm{c}$ & $18.6 \mathrm{e}$ & $19.3 \mathrm{f}$ & $10.7 \mathrm{~b}$ \\
\hline Mean & $1.5 \mathrm{a}$ & $5.9 \mathrm{~b}$ & $12.8 \mathrm{c}$ & $13.1 \mathrm{c}$ & & $1.3 \mathrm{a}$ & $2.4 \mathrm{~b}$ & $8.0 \mathrm{c}$ & $8.7 \mathrm{c}$ & \\
\hline
\end{tabular}

*Explanations: see Table 2 
Table 6. Effect of $24 \mathrm{~h}$ conditioning with cycloheximide or gibberellic acid on the soluble protein content [mg g-1 $\mathrm{d}$.w. in cut leaves of Zantedeschia aethiopica

\begin{tabular}{lccccc}
\hline \multirow{2}{*}{ Treatment } & \multicolumn{3}{c}{ Soluble protein content on day } & \multirow{2}{*}{ Mean } \\
\cline { 2 - 5 } & 0 & 5 & 11 & 15 & $152.5 \mathrm{~b}$ \\
$\mathrm{H}_{2} \mathrm{O}($ control $)$ & $189.2 \mathrm{e}^{*}$ & $181.0 \mathrm{de}$ & $146.6 \mathrm{c}$ & $93.0 \mathrm{~b}$ & $203.4 \mathrm{c}$ \\
$0.25 \mathrm{mmol} \mathrm{dm}^{-3} \mathrm{GA}_{3}$ & $189.2 \mathrm{e}$ & $262.3 \mathrm{f}$ & $184.6 \mathrm{e}$ & $177.4 \mathrm{de}$ & $116.2 \mathrm{a}$ \\
$1000 \mu \mathrm{mol} \mathrm{dm}{ }^{-3} \mathrm{CHI}$ & $189.2 \mathrm{e}$ & $172.1 \mathrm{~d}$ & $54.5 \mathrm{a}$ & $48.8 \mathrm{a}$ & $106.4 \mathrm{a}$ \\
\hline Mean & $189.2 \mathrm{c}$ & $205.1 \mathrm{~d}$ & $128.6 \mathrm{~b}$ & 100 \\
\hline
\end{tabular}

*Explanations: see Table 2

Table 7. Effect of $24 \mathrm{~h}$ conditioning with cycloheximide or gibberellic acid on the free amino acid content [ $\mu$ mol (leucine) $\mathrm{g}^{-1} \mathrm{~d}$.w.] and free proline content $\left[\mu \mathrm{mol} \mathrm{g}{ }^{-1} \mathrm{~d}\right.$.w. $]$ in cut leaves of Zantedeschia aethiopica

\begin{tabular}{|c|c|c|c|c|c|c|c|c|c|c|}
\hline \multirow{2}{*}{ Treatment } & \multicolumn{4}{|c|}{ Free amino acids content on day } & \multirow{2}{*}{ Mean } & \multicolumn{4}{|c|}{ Free proline content on day } & \multirow{2}{*}{ Mean } \\
\hline & 0 & 5 & 11 & 15 & & 0 & 5 & 11 & 15 & \\
\hline $\mathrm{H}_{2} \mathrm{O}$ (control) & $204.4 \mathrm{a}^{*}$ & $307.4 \mathrm{c}$ & $343.5 \mathrm{e}$ & $344.8 \mathrm{~d}$ & $300.0 \mathrm{~b}$ & $9.4 \mathrm{a}$ & $37.5 \mathrm{c}$ & $73.4 \mathrm{e}$ & $60.1 \mathrm{~d}$ & $45.1 \mathrm{~b}$ \\
\hline $0.25 \mathrm{mmol} \mathrm{dm}^{-3} \mathrm{GA}_{3}$ & $204.4 \mathrm{a}$ & $312.4 \mathrm{c}$ & $248.2 \mathrm{~b}$ & $229.3 \mathrm{ab}$ & $248.6 \mathrm{a}$ & $9.4 \mathrm{a}$ & $24.2 \mathrm{~b}$ & $29.3 \mathrm{~b}$ & $9.8 \mathrm{a}$ & $18.2 \mathrm{a}$ \\
\hline $1000 \mu \mathrm{mol} \mathrm{dm}{ }^{-3} \mathrm{CHI}$ & $204.4 \mathrm{a}$ & $570.2 \mathrm{f}$ & $663.9 \mathrm{~g}$ & $872.8 \mathrm{~h}$ & $577.8 \mathrm{c}$ & $9.4 \mathrm{a}$ & $137.3 \mathrm{f}$ & $159.2 \mathrm{~g}$ & $199.2 \mathrm{~h}$ & $126.3 \mathrm{c}$ \\
\hline Mean & $204.4 \mathrm{a}$ & $399.7 \mathrm{~b}$ & $455.2 \mathrm{bc}$ & $482.3 \mathrm{c}$ & & $9.4 \mathrm{a}$ & $66.4 \mathrm{~b}$ & $87.3 \mathrm{c}$ & $89.7 \mathrm{c}$ & \\
\hline
\end{tabular}

*Explanations: see Table 2

The contents of free amino acids, free proline included, increased during the experiment in hosta leaves, both those unconditioned and conditioned with CHI (Tab. 4). Only conditioning with BA resulted in a small decrease in free proline relative to the initial value. Its content was lower than directly after harvest only in the BA-treated leaves on the $13^{\text {th }}$ and $18^{\text {th }}$ day.

The pattern of changes in the contents of free amino acids in calla leaves was similar (Tab. 7). The highest values were found in the CHI-conditioned leaves, where on the $15^{\text {th }}$ day their content was over four times higher than directly after harvest. In $\mathrm{CHI}$-treated leaves an enormous rise in free proline occurred, 15 -fold and 21 -fold on the $5^{\text {th }}$ and $15^{\text {th }}$ day, respectively, while the final increase was 6-fold in the control untreated leaves.

\section{DISCUSSION}

As flower arrangements become more attractive due to the presence of green elements, the importance of cut greens on the flower market will continue to increase. Depending on the species or cultivar, the loss of decorative value in cut plant elements may be manifested differently. Cut leaves or shoots differ in their response to growing conditions, the environmental conditions during turnover and postharvest treatments. Certain substances effectively delaying senescence in some plants may hasten the loss of decorative value in other species (Skutnik et al. 2001). To increase the postharvest longevity of cut plant material, preservatives (Pun and Ichimura 2003) and plant hormones (van Doorn et al. 1992) are used. As proteolysis is involved in plant senescence, protease inhibitors have been proposed to delay protein degradation and to improve cut flower keeping qualities (Wulster et al. 1982). Inhibitors such as puromycin, actomycin and chloramphenicol have been tested in this regard but the most studied has been cycloheximide (Cashmore 1976) as the most effective compound inhibiting the synthesis of proteolytic enzymes (McMahon 1975, Rzychoń et al. 2004). Trials on the application of $\mathrm{CHI}$ in order to prolong vase life have till now been conducted mostly on cut flowers, where the compound effectively delayed senescence maintaining high protein level in floral tissues. Sultan and Farooq (1997) reported an increase of longevity in cut irises. Similar observations can be found for cut daylily (Hemerocallis hybrida) (LayYee et al. 1992), carnation (Dianthus caryophyllus semperflorens) (Drory et al. 1995), gladiolus (Gladiolus hybridus) (Yamane and Ogata 1995) and Dutch iris (Iris hollandica) (van Doorn et al. 1995). One can thus deduce that bud opening and flower wilting are associated with the synthesis of specific proteins. In the two hosta cultivars studied here, 'Minima Glauca' and 'Undulata Erromena', an increase in leaf longevity was obtained only after the application of a given $\mathrm{CHI}$ concentration:

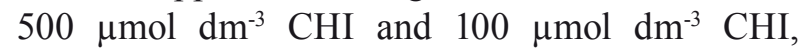
respectively. However, treatment with the inhibitor 
did not improved leaf longevity in calla (Tab. 1) nor in cut asparagus shoots (Skutnik and RabizaŚwider, unpublished data). The different response to $\mathrm{CHI}$ of particular species and cultivars may be associated with a different sensitivity to the inhibitor concentration. Gul and Tahir (2013) showed that in daffodil $\mathrm{CHI}$ in the concentration range between 0.01 and $0.05 \mathrm{mmol} \mathrm{dm}^{-3}$ delayed senescence, while in concentrations above 0.05 mmol dm ${ }^{-3}$ CHI prevented flower opening and promoted senescence.

Leaf senescence is under the control of plant hormones (Wingler et al. 1998), especially cytokinins, which effectively delay degradative processes in plant green elements used in floral arrangements (Skutnik et al. 2001, Skutnik et al. 2006, Skutnik and Rabiza-Świder 2007). Gibberellins also delay chlorophyll degradation in the leaves of certain species: Ethiopian calla (Skutnik et al. 2001), Easter lily (Lilium longiflorum) (Han 1997) and alstroemeria (Kappers et al. 1998). Growth regulators have been shown to be effective in delaying the senescence of Zantedeschia and Hosta leaves (Skutnik et al. 2001, Skutnik and Rabiza-Świder 2007).

The senescence-related proteolysis includes an increase in the cysteine protease activity. According to Rabiza-Świder et al. (2003), there was no expression of the cysteine protease gene in freshly harvested hosta leaves while the presence of its transcript was detectable in senescing leaves kept in water and the enzyme activity considerably increased. The conditioning of 'Minima Glauca' leaves with BA kept proteolytic activity and that of cysteine protease low. This was found earlier in hosta 'Undulata Erromena' and in calla (RabizaŚwider et al. 2003). Similar results were obtained in broccoli (Wang et al. 2004), where the activity of cysteine protease in florets treated with kinetin $\left(5 \mathrm{mg} \mathrm{dm}{ }^{-3}\right)$ was much lower than in untreated control flower heads four days after harvest. Such results confirm the key role of cysteine protease in the senescence of cut plant material.

The level of soluble proteins in leaf cells drops due to proteolysis. This drop is especially evident in cut leaves, which lose their ability to synthesize proteins after detachment from the mother plant (Rabiza-Świder et al. 2003). The smallest decrease in protein content was observed in hosta leaves conditioned in BA while it was more pronounced in leaves treated with CHI. In both cases the protein contents remained higher than in the untreated control. Similar results were reported by Sultan and
Farooq (1997) in iris where the flowers treated with the inhibitor contained more proteins than those placed directly into water. Gul and Tahir (2013) suggested that $\mathrm{CHI}$ maintained a high protein level in the petal issue by inhibiting the synthesis of specific proteases responsible for protein degradation. On the contrary, our calla leaves conditioned with $\mathrm{CHI}$ had the lowest protein level relative to other treatments. Similar results were noticed by Dar et el. (2015) in Dianthus, where the flowers pulsed with $0.1 \mathrm{mmol} \mathrm{dm}^{-3} \mathrm{CHI}$ maintained a lower soluble protein content in comparison to the control.

Due to protein degradation in detached plant elements, the accumulation of free amino acids occurs, as they cannot be transported out to other plant organs. In hosta and calla leaves cytokinins (Skutnik and Rabiza-Świder 2007) and gibberellins (Rabiza-Świder et al. 2004 a), respectively, are the most effective in preventing this phenomenon. Here, the lowest free amino acid content was found in hosta leaves conditioned with BA, where on the last sampling date it was threefold lower than in the control treatment and twofold lower than in the CHI-treated leaves. In calla leaves, the highest free amino acid accumulation resulted from the $\mathrm{CHI}$ treatment. At the end of the experiment it was several times higher than in leaves conditioned with $\mathrm{GA}_{3}$ and even exceeded that determined in the control untreated leaves. It is therefore evident that $\mathrm{CHI}$ did not delay processes typical for senescence such as protein degradation or the accumulation of free proline resulting from proteolysis, though this was expected as $\mathrm{CHI}$ inhibits protease activity. Gul and Tahir (2013) showed that the content of proteins decreased whereas that of amino acids increased in Narcissus flowers with CHI treatment, besides improving postharvest performance. Similar results were obtained in cut carnations, where the treatment of CHI resulted in an increase in the total amino acid pool (Dar et al. 2015). The question of why the vase life of cut flowers or leaves may be improved by $\mathrm{CHI}$ while the proteolytic activity is enhanced remains open.

During the senescence of detached plant organs, the accumulation of free proline commonly occurs as a plant response to water stress (Karolewski 1996). Yang et al. (2000) found a 17-fold increase in free proline 12 hours after the detachment of rice leaves and after four days this increase was 50 -fold. Comparable high proline content was determined in calla leaves conditioned with CHI: on the $15^{\text {th }}$ day it was three times higher than in the control untreated 
leaves and 20 times higher than immediately after harvest (Tab. 7). These results prove that senescence in calla leaves is closely associated with free proline accumulation, similarly as in rice (Yang and Kao 2000). Contrary to calla, in 'Minima Glauca' hosta the level of free proline was low and comparable to the initial amount, both for BA and CHI-treated leaves.

The above results indicate that senescence can proceed in different ways in cut flowers and leaves and that a treatment effective for cut flowers will not always give such results in detached leaves. $\mathrm{CHI}$, whose efficiency in delaying senescence in cut flowers has widely been proven, probably will not be recommended for the cut foliage of calla and hosta though its positive effects on other species cannot be excluded and further studies on other plants should be continued.

\section{CONCLUSIONS}

1. The effects of cycloheximide used on the cut foliage of calla and hosta depended on the species, cultivar and inhibitor concentration.

2. The application of CHI on cut leaves delayed decreases in soluble proteins and limited the accumulation of free proline in hosta but not in calla.

3. During the senescence of cut hosta leaves the proteolytic activity, including that of cysteine protease, increased, but this increase was reduced by conditioning with $\mathrm{BA}$.

4. In senescing calla leaves, the activity of proteolytic enzymes including that of cysteine protease increased, but was lower in leaves conditioned with $\mathrm{GA}_{3}$ and those placed into distilled water than in those treated with $\mathrm{CHI}$.

5. The use of growth regulators is recommended for increasing the vase life of cut leaves of hosta and calla, as they more efficiently delay senescence as compared to cycloheximide.

\section{FUNDING}

The study was supported by the Ministry of Science and Higher Education.

\section{AUTHOR CONTRIBUTIONS}

All authors contributed equally to this study. E.S. designed and performed the experiments and wrote the paper, J.R.-Ś. designed the experiments and performed analytical measurements, A.J. collected the data and performed statistical analyses, and D.M. performed analytical measurements.

\section{CONFLICT OF INTEREST}

The authors declare no conflict of interest.

\section{REFERENCES}

Bates L., Waldren L., Teare J., 1973. Rapid determination of free proline for water - stress studies. Plant Soil 39: 205-207.

BRADFORD M.M., 1976. A rapid and sensitive method for the quantitation of microgram quantities of protein utilizing the principle of protein-dye binding. Anal. Biochem. 72: 248-254.

Cashmore A.R., 1976. Protein synthesis in plant leaf tissue. The sites of synthesis of the major proteins. J. Biol. Chem. 251(9): 2848-2856.

Dar R.A., Tahir I., Ahmad S.S., 2015. Cycloheximide efficacy varies temporally in improving postharvest performance of cool we stored Dianthus chinensis L. cut sprays. Proc. Natl. Acad. Sci., India Sect. B Biol. Sci., DOI 10.1007/s40011-015-0584-Z.

Drory A., Beja-Tal S., Borochov A., Gindin E., Mayak S., 1995. Transient water stress in cut carnation flowers: effect of cycloheximide. Sci. Hortic. 64: 167-175.

Gul F., TAhir I., 2013. An effective for improving vase life and postharvest performance of cut Narcissus tazetta flowers. J. Saudi Soc. Agri. Sci. 12: 39-46.

Han S., 1997. Preventing postproduction leaf yellowing in Easter lily. J. Am. Soc. Hortic. Sci. 122: 869-872.

Kappers I.F., Jordi W., Maas F.M., Stoopen G.M., Van Der Plas L.H.W., 1998. Gibberellin and phytochrome control senescence in alstroemeria leaves independently. Physiol. Plant. 103: 91-98.

Karolewski P., 1996. Role of proline in higher plants under conditions of abiotic stress. Wiad. Bot. 40: 6781.

Lay-Yee M., Stead A.D., Reid M.S., 1992. Flower senescence in daylily (Hemerocallis). Acta Physiol. Plant. 86: 308-314.

McMahon D., 1975. Cycloheximide is not a specific inhibitor of protein synthesis in vivo. Plant Physiol. 49: 64-71.

Nooden L.D., Guiament J.J., 1996. Genetic control of senescence and aging plants. Physiol. Plant. 116: 416-421.

Pun U.K., Ichimura K., 2003. Role of sugars in senescence and biosynthesis of ethylene in cut flowers. Jpn Agric. Res. Q. 37(4): 219-224.

Rabiza-Świder J., Rybka Z., Skutnik E., Łukaszewska A.J., 2003. Proteolysis and expression of the cysteine pro tease gene in senescing cut leaves of Hosta 'Undulata Erromena' and Zantedeschia aethiopica Spr. treated with BA or GA 3 . Acta Physiol. Plant. 25: 319-324. 
Rabiza-ŚWider J., SkUtNiK E., Wachowicz M., Łukaszewska A.J., 2004a. Senescence of cut leaves of Zantedeschia aethiopica and Z. elliotiana. Part II. Free amino acids accumulation in relation to soluble protein content. Acta Sci. Pol. Hortorum Cultus 3(2): 67-74.

Rabiza-Świder J., Łukaszewska A.J., Skutnik E., LeszKo M., 2004b. Ammonium and proline accumulation in senescing cut leaves of Zantedeschia. Acta Physiol. Plant. 26(4): 417-422.

Rosen H., 1957. A modified ninhydrin colometric analysis for amino acids. Arch. Biochem. Biophys. 67: 10-15.

Rzychoń M., Chmiel D., Stec-Niemczyk J., 2004. Modes of inhibition of cysteine proteases. Acta Biochim. Pol. 54(4): 861-873.

Skutnik E., Łukaszewska A., Serek M., Rabiza J., 2001. Effect of growth regulators on postharvest characteristics of Zantedeschia aethiopica. Postharvest Biol. Technol. 21: 241-246.

SkutNik E., Rabiza-Świder J., 2005. Effect of pulsing with growth regulators on senescence of the detached cold-stored leaves of Zantedeschia aethiopica spr. and Hosta 'Undulata Erromena'. Acta Sci. Pol. Hortorum Cultus 4(2): 101-110.

SkUtNik E., RabizA-Świder J., 2007. Effect of plant growth regulators and preservative solutions on senescence of detached hosta leaves. Ann. Warsaw Univ. Life Sci. - SGGW, Horticult. Landsc. Architect. 28: 95-103.

SKutnik E., RabizA-Świder J., ŁukAszewska A., 2006. Evaluation of several chemical agents for prolonging vase life in cut asparagus greens. J. Fruit Ornam. Plant Res. 14: 233-240.

Skutnik E., Rabiza-Świder J., Wachowicz M., LuKAsZewsKA A., 2004. Senescence of cut leaves of Zantedeschia aethiopica and Z. elliottiana. Part I. Chlorophyll degradation. Acta Sci. Pol. Hortorum Cultus 3(2): 57-65.

Strzelecka H., Kamińska J., Kowalski J., Walewska E., 1982. Chemiczne metody badań roślinnych surowców leczniczych (Chemical Methods of Analyses of Plant Raw Materials). PZWL Warszawa:164.

Sultan S.M., Farood S., 1997. Effect of cycloheximide on some physiological changes associated with senescence of detached flowers of Iris germanica L. Acta Physiol. Plant. 19(1): 41-45.

van Doorn W.G., Hibma J., de Wit J., 1992. Effect of exogenous hormones on leaf chlorosis in cut flowering branches of Alstroemeria pelegrina. Plant Growth Regul. 11: 59-62.

van Doorn W.G., Harkema H., Song J.S., 1995. Water relations and senescence of cut Iris flowers: effects of cycloheximide. Postharvest Biol. Technol. 5: 345 351.

Wang Y.T., Yang C.Y., Chen Y., Lin Y., Shaw J., 2004. Characterization of senescence - associated proteases in postharvest broccoli florets. Plant Physiol. Bioch. 42: 663-670.

Wingler A., Von Schaewen A., Leegood R.C., Lea P.J., Quick W.P., 1998. Regulation of leaf senescence by cytokinin, sugar and light. Plant Physiol. 116: 329335.

Wulster G., Sacalis J., Janes H., 1982. The effect of inhibitors of protein synthesis on ethylene induced senescence in isolated carnation petals. J. Am. Soc. Hortic. Sci. 107: 112-115.

Yamane K., Ogata R., 1995. Effect of cycloheximide on physiological parameters of Gladiolus florets during growth and senescence. J. Jpn. Soc. Hortic. Sci. 64(2): 411-416.

YANG C.W., KAO C.H., 2000. Ammonium in relation to proline accumulation in detached rice leaves. Plant Growth Regul. 30: 139-144.

YANG C.W., Lin C.C., KAO C.H., 2000. Proline, ornithine, arginine and glutamine acid contents in detached rice leaves. Plant Biol. 43: 305-307.

ZAGDAŃSKA B., WIŚNIEWSKI K., 1996. Endoproteinase activities in wheat leaves upon water deficit. Acta Biochim. Pol. 43: 515-520.

Received August 31, 2015; accepted November 19, 2015 